\title{
ENVIRONMENTAL RISK REGULATION IN THE ENVIRONMENTAL PROTECTION LAW OF THE REPUBLIC OF SLOVENIA
}

The purpose of this paper is to present an overview of the regulation of environmental protection in force in administrative law in the Republic of Slovenia. The author analyses basic environmental protection principles which are contained in the EU regulation. These principles are: (1) the precautionary principle (le principe de précaution, der Grundsatz der Vorsorge), (2) the principle of preventive action (le principe d'action préventive, der Grundsatz der Vorbeugung), (3) the principle of correction at source (le principe de correction à la source, der Grundsatz, Umweltbeeinträchtigungen mit Vorrang an ihrem Ursprung zu bekämpfen), and (4) the polluter pays principle (le principe de pollueurpayeur, das Verursacherprinzip).

In order to accede to the EU, the Republic of Slovenia in Article 3 a of the Constitution of the Republic of Slovenia allowed the supremacy of the primary legislation of the EU over Slovenian national regulations. The above-mentioned principles of the EC Treaty are transposed into the legal system of the Republic of Slovenia by means of its environmental legislation and implementing regulations. In this paper the author analyses the public law regulation contained primarily in the Environmental Protection Act (Official Gazette RS, Nos. 39/2006, 20/2006, and 70/2008). In addition to the general regulation implemented already by the Environmental Protection Act of 2006, the last amendment to the Environmental Protection Act transposed into the Slovenian legal order the provisions of Directive 2004/35/CE of the European Parliament and of the Council of 21 April 2004 on environmental liability with regard to the prevention and remedying of environmental damage.

The paper focuses on the administrative legal regulation of the prevention and reduction of burdens on the environment, the conservation and improvement of the quality of the environment, the remedying of the consequences of burdens on the environment, as well as the improvement of the disrupted natural equilibrium and the recovery of its regenerative capacity. The paper furthermore analyses the application of the Environmental Protection Act as a general substantive law, as well as the special application of the procedures provided for in the Environmental Protection Act against subsidiary regulation of general administrative procedures in cases in which public and private interests are in collision or in potential collision.

Key words: administrative law, environmental protection, the precautionary principle, the principle of preventive action, the principle of correction at source, the polluter pays principle

\section{Introduction}

The substantive foundation of contemporary transnational and national regulation of environmental protection in administrative law in democratic societies in recent decades is no longer an anthropocentric perception of nature, i.e. that nature is exclusively subordinate to humans (Greek: anthropeioi nomos), but rather a new, ecocentric perception of nature (Greek: nomos theios). According to ecocentrism, the centre of legal protection is nature and not the exploitation of nature by humans. In light of the fact that anthropocentrism (i.e. in the sense of exploitation by humans) as a basis for human interaction with nature has led to the damaging and in some places even to the complete destruction of nature, there is no doubt that the ecological reasoning which lies within the anthropocentric perception of nature cannot lead to its protection. Legal protection of nature can only be achieved by establishing an ecocentric foundation in positive law regulation. This direction must also be followed by contemporary national and transnational legislation - Greek nomos (see Pličanič, 1999; 16-30; Kirn 1992, 5-22).

The ecocentric foundation of the regulation of nature has been followed in the last two decades by cogent (Latin: ius cogens compelling law) regulation of European and Slovenian administrative law through the system of positive law (Latin: ius positivum applicable law) institutional and instrumental regulations. The term institutional regulations primarily refers to the highest legal acts which establish a value framework for the legal system (see Parsons, 1978). These are especially the primary European legislation (i.e. the Treaty Establishing the European Community - hereinafter referred to as the EC Treaty) and the Constitution of the Republic of Slovenia (hereinafter referred to as the Constitution). The term instrumental regulations, on the other hand, refers to national laws and implementing regulations which implement the value-based aims established at the institutional level in positive law.

\footnotetext{
* Bojan Ticar

Faculty of Criminal Justice and Security of the University of Maribor, Department at the University of Primorska, Faculty of Management of the University of Primorska., Slovenia, E-mail: bojan.ticar@fvv.uni-mb.si
} 
The national regulation of environmental protection in administrative law in the Republic of Slovenia is a fairly new legal discipline that has existed and been developing only for the last two decades within the framework of graduate and post-graduate studies at Slovenian universities. Conceptually, this entails studying environmental law, which at the transnational and national levels enacts moderation in activities affecting nature.

With reference to such, it can be established that EU principles are also in conformity with the Slovenian Constitution, which in Section III, regulating economic and social relations, ensures everyone the protection of a healthy living environment (Article 72 of the Constitution) and the protection of the natural heritage (Article 73 of the Constitution). In this connection, the Constitution also addresses the concepts of national asset and natural resource (Article 70 of the Constitution). With reference to all the above-mentioned constitutionally protected values, the Constitution instructs the legislature to adopt the appropriate national legislation thereon. In addition, also Article $3 \mathrm{a}$ of the Constitution, which was added in 2003 as the basis, and one of the requirements of the EU, for Slovenia to join the EU, cannot be neglected. On the basis of this provision the Republic of Slovenia recognises the supremacy of the primary EU legislation over national legislation in the creation of the national legal order. The above-mentioned principles and constitutionally protected rights are implemented in the Slovenian legal order through national regulations, first of all through the Environmental Protection Act (hereinafter referred to as the EPA$1)$.

The above-mentioned Act introduced the institutional regulation of environmental protection, as laid down in the European treaty and the Slovenian Constitution, through thirteen fundamental principles. These are the following: (1) the principle of sustainable development, (2) the principle of integration, (3) the principle of cooperation, (4) the principle of prevention, (5) the precautionary principle, (6) the principle of the accountability of the person responsible for a burden on the environment, (7) the principle of payment for causing a burden on the environment, (8) the principle of subsidiary action, (9) the principle of incentives, (10) the principle of public access to information, (11) the principle of the protection of rights, (12) the principle of the admissibility of activities affecting the environment, and (13) the principle of the ecological function of property (Articles 4 to 16 of the EPA-1).

However, the EPA-1 is not the only Slovenian regulation that regulates the environment. There is a whole range, depending on the special regulation which each individual aspect of the environment requires. Slovenian environmental law can, in the broader sense, be divided into five parts related in terms of content (see Scripta UL PF No. 35., 2008: 166-168), namely: (1) the legal regulation of natural assets and the conservation of biotic diversity, (2) the legal regulation of water management, (3) the legal regulation of mineral matters management (non-renewable natural resources), (4) the legal regulation of wild animal management (hunting and fishing), and (5) the legal regulation of forests and barren land management.
This paper will not deal with specific and special regulations. It can be mentioned, however, that for a profound understanding of the structure of the national legal order in the field of environmental law, the rule lex specialis derogat lege generali must be applied. This entails that in the event of a collision of statutory rights and obligations, when two laws regulate the same legal relation, the regulation of the law which is more specialised - in the sense of Latin lex specialis - prevails. The EPA-1 is a general regulation. In individual specific environmental law fields the regulation determined in special regulations will thus prevail, inasmuch as they regulate specific environmental relations in a specific and special manner.

The central term of modern environmental law is the subjective law of persons subject to environmental law - their legal rights and duties. They are based on the general constitutional right of individuals to a healthy living environment. This is a general right which is followed by special rights and duties regulated by special laws in accordance with the principle of speciality. This right is in general a legally protected entitlement (Latin: facultas agendi) that a legal subject can act in a certain manner. This right is composed of two entitlements, namely of a fundamental entitlement and a claim. A fundamental entitlement enables subjects to fulfil their own interests if such are in compliance with the legal aim of the entitlement. A claim, on the other hand, contains the possibility that the state will impose a coercive sanction in the interest of the subject if another subject does not act in compliance with the obligation. The right thus contains, on one hand, an entitlement of one subject, and, on the other hand, the duty or obligation of another subject. Therefore, from a broader perspective (e.g. in interest-volition theory), a legal right is both - a right and a duty entitlement of the legal subject (CZ, Pravo, 2003: 264).

In what manner administrative law rights and duties of subjects to environmental law are implemented in accordance with the Slovenian EPA-1 will be discussed below. The paper will focus on the question of environmental protection permit as an individual administrative act and through this, the regulation of the supervision of state authorities regarding violations of administrative law statutory provisions from the field of environmental protection.

\section{Environmental Protection Permit in Slovenian Legislation}

The environmental protection permit is a central concrete and individual administrative act that every entity responsible for a planned activity must obtain in accordance with Slovenian legislation (Article 57 of the EPA-1). In order to operate an installation or plant where any activity that might cause large-scale environmental pollution will be carried out, the operator must obtain an environmental protection permit. However, the EPA-1 introduces various types of environmental protection permits which differ with regard to the scope of the requirements that must be fulfilled in order to be obtained, with regard to the time limits for issuing the permit, and with regard to the participation of the public; all types of permits are, however, issued by the Ministry of the Envi- 
ronment and Spatial Planning or its affiliated body, i.e. the Environmental Agency of the Republic of Slovenia (hereinafter referred to as the EARS). An environmental protection permit must be obtained prior to the beginning of the operation of the installation or plant and for every substantial change in the operation of an installation or plant. A substantial change in the operation thereof is (1.) any change in the installation or its extension that modifies any principal technical characteristic of the installation or its capacity, which as a consequence causes a change in the quantity or type of emissions into the environment or the waste for which the environmental protection permit was obtained, (2.) a considerable increase in the quantity of a hazardous substance, (3.) a significant change in the chemical or physical properties of a hazardous substance, or (4.) any other change in the technological process in a plant where a hazardous substance is used. An environmental protection permit must be obtained in three instances (see VilerKovačič, 2006: 6-7), namely:

- For installations that may cause large-scale pollution, i.e. installations subject to the IPPC Directive. The abbreviation derives from the title of the EU directive, namely Council Directive 96/61/EC concerning integrated pollution prevention and control, abbreviated as the IPPC Directive. This directive regulates IPPC installations.

- For other installations that do not cause large-scale pollution (installations determined in Article 82 of the EPA-1):

0 if an activity is pursued in these installations that causes emissions into the air, water, or soil for which limit values are prescribed;

0 if an activity is pursued in these installations for which the obligation to obtain an environmental protection permit is prescribed in other regulations;

0 if in these installations waste is treated or disposed of.

- For installations that pose a major environmental risk.

Pursuant to the EPA-1, an installation is any stationary or mobile technical unit for which it has been established that it may cause an environmental burden as a consequence of one or more specified technological processes taking place in that installation, or of any other technology-related processes taking place at the same site (item 8 of Article 3 of the EPA-1). In accordance with the same Act, a plant is defined as the entire area managed by one operator where there are one or more installations, including the accompanying or associated infrastructure and technological processes related thereto in which hazardous substances are produced, stored, or used in any other way (item 9 of Article 3 of the EPA-1).

In what manner European legislation is applied at the national level will be demonstrated through the case study of the application of the Seveso Directive into the Slovenian EPA-1 (Viler-Kovacic, 2006: 6-7):

CASE STUDY: A particularity of the environmental protection permit in the Slovenian legal system is also the transposition of the Seveso European Directive for plants into the EPA-1 (see Article 86 of the EPA-1). The Council of the European Union adopted the Seveso
Directive (i.e. Council Directive 96/82/EC of 9 December 1996 on the control of major-accident hazards involving dangerous substances) following a major accident in Seveso in Italy in 1976, when several kilograms of dangerous dioxin was suddenly and uncontrollably released from the chemical plant and contaminated more than 15,000 $\mathrm{m} 2$ of land and vegetation. As many as 2000 people were treated for dioxin poisoning and more than 600 had to be evacuated from their homes (see http://europa.eu.int/comm/environment/seveso/\#1, 20. 11. 2009).

The above-mentioned directive was transposed into the EPA-1 through the requirement that when operating a plant, the person posing a risk to the environment must implement the prescribed measures for the prevention of any major accident and for the mitigation of consequences therefrom for humans and the environment, and in particular draw up a scheme for the reduction of environmental risk and a safety report. A person posing a risk to the environment must obtain an environmental protection permit for the plant, which is named an environmental protection permit issued in accordance with Article 86 of the EPA-1 or a Seveso permit, in order to distinguish it from other environmental protection permits.

Operators of such plants are termed persons posing a risk to the environment, whereas a risk to the environment in accordance with the EPA-1 entails the probability that in certain circumstances or within a certain time interval an activity would harm, directly or indirectly, the environment, or human life or health. The measures that the plant operators must undertake for the prevention of major accidents and the mitigation of their consequences for humans and the environment, as well as safety measures connected therewith which plant operators must meet, are regulated by the Government Decree on the Prevention of Major Accidents and the Mitigation of their Consequences (Official Gazette RS, No. 88/2005). Pursuant to this Decree, plants are divided into plants posing a lower risk to the environment and plants posing a greater risk to the environment, regardless of the type and quantity of hazardous substances that are in the plant. A formula for the assessment of a plant posing a lower risk to the environment and those posing a greater risk to the environment is provided in the annex to the Decree.

In the procedure for issuing the environmental protection permit, the EARS must make the permit application and the draft decision on the environmental protection permit available to the public. The provisions that apply to entities subject to the IPPC Directive apply, mutatis mutandis, regarding the participation of the public. The time limit for issuing a permit is three months from receiving a complete application.

The environmental protection permit stipulates in detail measures for the prevention of major accidents and the mitigation of their consequences for humans and the environment; the environmental protection permit is issued for a period of five years from the day of the beginning of the operation of the plant (and not from the day this administrative act takes effect). In the event that it is assessed that the consequences of a major accident in a plant could have an impact on the environment of another state, or when the latter so requests, the competent authority of that state is to be informed of the environmen- 
tal protection permit issued. If on the basis of such information another state so requests, it must be forwarded the safety report of the plant in question.

Such environmental protection permit may also be extended, updated, or withdrawn under the conditions and in the manner determined by the EPA-1.

\section{Administrative Supervision of Environmental Protection}

Administrative supervision, particularly inspection, is one of the administrative functions of the state that ensures supervision of the implementation of the adopted legal order and provides feedback so that administrative bodies can learn of the effects of the adopted regulations and introduce appropriate modifications and measures. The coercive nature of inspection tasks ensures that addressees of legal norms respect regulations, whereas at the same time these norms protect the rights and legal benefits of individuals that were recognised to them by laws and other regulations. Inspection supervision is thus supervision of the implementation of laws and other regulations. The tasks of inspection are performed by inspectors as officials with special authorisations and responsibilities (see Likozar-Rogelj, 2006: 16-17).

The nature of performing inspection tasks is repressive. Therefore, the primary task of inspectors is not to give advice or instruct parties to obtain the necessary permits, but to impose measures if addressees (i.e. persons subject to inspection) do not have the permits which they are required to have. This also applies to environmental protection permits regulated in the EPA-1.

If an environmental inspector establishes that a person liable for the operation of a plant or installation does not have the necessary environmental protection permit, he or she does not instruct the person liable to obtain such permit, as the author of the abovecited article erroneously thinks, but prohibits the operation of the installation or plant if it is operating without an environmental protection permit (see item 6 of the first paragraph of Article 157 of the EPA-1). As the legislature determined that the operation of a plant or installation without obtaining a prior environmental protection permit is prohibited, it provided for the imposition of sanctions; a legal entity may be imposed a fine in the amount of 1,200 to 360,000 EUR. Due to the fact that the amount of the prescribed sanction that can be imposed is high, accelerated minor offence proceedings are not allowed (Likozar-Rogelj, 2006: 16-17).

It thus proceeds from the above-mentioned that inspectors must respect the principle of legality when performing their tasks. They implement this fundamental principle through supervision, as they supervise in the public interest whether the adopted legal regulations are respected and take appropriate measures in cases in which they establish a violation of the regulations that they are authorised to supervise. The repressive nature of inspection tasks is demonstrated solely through measures which inspectors are obliged to impose if they establish that the legal order is not respected.

\section{Conclusion remarks}

In 2006 the Inspection Act (hereinafter referred to as the IA) introduced an amendment that authorises inspectors to apply preventive measures (see Article 33 of the IA) which concretise the principle of the protection of the public interest and the protection of private interests in order to ensure that the regulations are respected. Inspectors can namely only issue a warning if they establish irregularities when performing their inspection tasks and asses that such is an appropriate measure regarding the seriousness of the violation. They also determine a time limit in which the irregularities must be remedied. If the irregularities are not remedied, inspectors impose other measures in accordance with the law. The above-mentioned discretionary right of inspectors importantly influences the preventive action; depending on the seriousness of the violation, inspectors assess whether a warning will suffice and whether the person subject to inspection will respect the norms of the regulation and perform the omitted prescribed obligation or remedy the violation which they have caused with their operation. If, however, inspectors establish that after a warning has been issued, a person subject to inspection does not respect the imposed measure, they are to impose other, graver measures prescribed by law. A person subject to inspection is obliged to remedy the irregularities or deficiencies within the determined time limit; if they do not do so themselves, the inspectors force them to remedy such in execution proceedings with the execution carried out by a third person or by a fine. Inspectors thus do not only impose measures, but also ensure that such measures are implemented (LikozarRogelj, 2006: 17).

\section{References}

[1] Council Directive 96/61/EC of 24 September 1996 concerning integrated pollution, prevention and control - IPPC Directive.

[2] Council Directive 96/82/EC of 9 December 1996 on the control of major-accident hazards involving dangerous substances.

[3] KIRN, A.: Ecological Ethics (in Slovenian), 1. Nat, Aram, Maribor, 1992.

[4] Leksikon Cankarjeve zalozbe: Right (in Slovenian), CZ, Ljubljana, 2003.

[5] LIKOZAR-ROGELJ, M.: Ecological Permit - Inspectional Control (in Slovenian), Pravna praksa, No. 21, GV. Zalozba d.o.o., Ljubljana, p. 14, 2006.

[6] Littera, Scripta, Manet, 35. publikacija iz zbirke Scripta (2008), Program podiplomskega studija Pravne fakultete v Ljubljani 2008/2009.

[7] PARSONS, TALCOTT: Action Theory and the Human Condition, New York : Free Press, 1978. 
[8] PLICANIC, S.: Human or Nature? New-age Law of Nature: "Anthropeioi nomos" or "Nomos theios" (in Slovenian), razprava o razlogih "unicenja Narave" in o novoveskem pravu narave kot pravu unicevalcev Narave, Zbornik znanstvenih razprav Pravne fakultete v Ljubljani. Vol. 59, 1999.

[9] Contract of European Union (in Slovenian) (PEU), Uradni list EU, C 325/108, 24.12.2002 - http://eur-lex.europa.eu/LexUriServ/LexUriServ.do?uri=OJ:C:2008:115:0013: 0045:SL:PDF (16.11.2009)

[10] T.M.C. Asser Institut, Hague - European Environmental Law Network, http://www.asser.nl/default.aspx?site_id=7 (18.11.2009)

[11] Regulation of Prevention Larger Accidents and Damage Limitation (in Slovenian), Ur. 1. RS, st. 88/05.

[12] Constitution of the Republic Slovenia (URS) Ur.1. RS, st. 33I/1991-I, 42/1997, 66/2000, 24/2003, 69/2004, 69/2004, 69/2004, $68 / 2006$.

[13] VILER-KOVACIC, A.: Ecological Permit (in Slovenian), Pravna praksa, let. 2006, st. 19, GV. Zalozba d.o.o., Ljubljana, p. 6, 2006.

[14] VILER-KOVACIC, A.: Measures for European Environmental Legislative (in Slovenian), Pravna praksa, let. 2008, st. 26, GV, Zalozba d.o.o., Ljubljana, p. 30, 2008.

[15] VUJOSEVIC, N.: Guiding Principle for Ecological Standards ISO 14001 in EMAS (in Slovenian), GV Zalozba, Ljubljana, 2006.

[16] Law of Inspectional Control (in Slovenian), Ur.l. RS, st. 56/200226/2007, 43/2007 ZIN-UPB1.

[17] Environment Protection Law (in Slovenian), Ur.l. RS, st. 41/2004, 17/2006, 20/2006, 28/2006 Skl.US: U-I-51/06-5, 39/2006UPB1, 49/2006-ZMetD, 66/2006 Odl.US: U-I-51/06-10, 112/2006, uradno precisceno besedilo ZVO-1-UPB1 Ur.1. RS, st. 39/2006Odl.US: U-I-40/06-10, 33/2007-ZPNacrt, 57/2008-ZFO-1A, 70/2008 -ZVO-1. 